\title{
Are E-Cigarettes Safer than Cigarette Smoking?
}

\author{
Novikova NU, Laushkin MA*, Lopatin ZV and Kopylov ED \\ North-western State Medical University named after Mechnikov, Russia \\ *Corresponding author: Laushkin MA, North-western State Medical University named after Mechnikov, Russia
}

\begin{tabular}{l}
\hline ARTICLE INFO \\
\hline
\end{tabular}

Received: 幽 February 05, 2021

Published: 蔧 February 11, 2021

Citation: Novikova NU, Laushkin MA, Lopatin ZV, Kopylov ED. Are E-Cigarettes Safer than Cigarette Smoking?. Biomed J Sci \& Tech Res 33(5)-2021. BJSTR. MS.ID.005462.
E-cigarettes were created to fight against nicotine addiction. But the mechanism of their work and many components they contain are not as safe as people think. This misleading situation increases the risks of negative consequences. This study reviews data on toxicological characteristics of the components that e-cigarettes contain and analyzes their influence on human body. Since new mechanisms of nicotine intake are gaining popularity, it is necessary to develop relevant methods of disease prevention.

Keywords: E-cigarettes; Toxic Components

\section{Introduction}

Cigarette smoking is one of the global problems in the modern world. Due to the latest research, the number of people who smokes cigarettes is getting lower and is estimated as 1.3 billion. At the same time, the number of people who smoke e-cigarettes is increasing dramatically every year and has now reached approximately 50 million people [1]. That is why it is necessary to know and be able to predict the consequences of e-cigarettes use.

\section{Materials and Methods}

391 students $(243(62,1 \%)$ and $148(37,9 \%)$ women and men, respectively) at the age of $23 \div 4,5$ were the participants of this research. The methods of the research was questioning and it's analyzing. The questionnaire included the following questions: participants' gender, how long they have been smoking, smoking tobacco before vape, reasons to start smoking e-cigarettes, preference in e-cigarettes or tobacco smoking.

\section{Results}

According to manufacturers, the main difference between e-cigarettes and conventional cigarettes is their purpose by replacing bitter smoke with multicolored, fragrant vapor, vapes contribute to getting rid of the habit of tobacco smoking by gradually reducing the nicotine content. To indicate the liquid by the nicotine content, the following designations are used in order of increasing strength: $0 \mathrm{mg}$ - 0\% (0 mg/ml); $1.5 \mathrm{mg}$ - 0.15\% (1.5 mg/ml); $3 \mathrm{mg}$ $0.3 \%$ ( $3 \mathrm{mg} / \mathrm{ml}$ ); $6 \mathrm{mg}-0.6 \%$ (6 mg/ml); $12 \mathrm{mg}-1.2 \%$ (12 mg/ml). Nevertheless, the amount of nicotine in one puff depends on the power supplied to the vaporizer. The more power is fed, the more vapor is generated and, accordingly, more nicotine is produced per serving [2]. However, manufacturers statement about safety can be argued. First, in addition to nicotine, e-cigarettes contain many other components that are not safe at all. Second, according to the results of the study, almost half of the students surveyed (42\%) did not smoke before buying an electronic cigarette, saying that the reasons for starting smoking were the pleasant taste of electronic cigarettes (41\%), their calming effect (12\%) and fashion for vapes (8\%). But, unfortunately, $39 \%$ of respondents were encouraged to buy this device mistakenly considering vapes safe. Note: another common misbelief in addition to their harmlessness, is that e-cigarettes contribute to the abandonment of any alternative smoking methods (cigarettes, hookahs). But judging by the responses of students, more than half of them (55\%) have not been able to completely give up from smoking analogues and use them together with vapes. E-cigarettes are also highly addictive. This can be concluded from the results of the survey of students, according to which almost $80 \%$ of respondents smoke for a long time (from one to seven years). Also, among these respondents (391 people) more than a half $(62,1 \%)$ are women, which indicates dependence on gender [3-7].

\section{Discussion}

However, despite the strong dependence of consumers on e-cigarettes, $34 \%$ of respondents still prefer cigarettes to vapes. Based on the data obtained, e-cigarette smokers are in a 
misconception about their safety. There is a need for careful review of their composition to refute false judgments, to inform users of electronic devices in order to prevent morbidity. In addition to the nicotine already mentioned, e-cigarettes contain equally dangerous components such as glycerin, propylene glycol, dyes and flavors. These substances can cause diseases related to the functioning of the gastrointestinal, kidney, liver, respiratory and nervous systems, as well as can cause cancer, irritation of the skin, eyes and mucous membranes, leading to serious disorders of the body. Analysis of the composition of e-cigarettes indicates that there is not a single

Table 1. component in the vapers that would be safe for the human body. From all of the above mentioned we can conclude about the harmful effect of e-cigarettes on the body as a whole. Therefore, they cannot be called a completely safe alternative to tobacco smoking. This belief is false. Of course, research on the effects of e-cigarettes is important for the prevention and treatment of respiratory and cardiovascular diseases, oral mucosa and organism in general. Clearly, at the moment, the only and most rational method of preventing morbidity is the cessation of smoking e-cigarettes (Table 1).

\begin{tabular}{|c|c|c|}
\hline Components & $\begin{array}{l}\text { MPC (maximum permissible } \\
\text { concentration) }\end{array}$ & Influence on an organism \\
\hline Glycerol (steam formation, fluid density) & $10 \mathrm{mg} / \mathrm{m}^{3}$ & $\begin{array}{l}\text { Acne formation, darkening and excessive dryness of the skin, dry } \\
\text { mouth, persistent cough (glycerin draws moisture and dries the larynx } \\
\text { mucosa) disorders of the genitourinary system. } \\
\text { • vegetovascular dystonia. } \\
\text { • respiratory diseases. } \\
\text { - deterioration in the functioning of the kidneys and liver. } \\
\text { • lowering the wetness of the mucous membranes. } \\
\text { - deterioration in smell and a decrease in the functioning of taste } \\
\text { receptors. }\end{array}$ \\
\hline $\begin{array}{l}\text { Propyleneglycol (faster entry of nicotine } \\
\text { into the body) }\end{array}$ & $7 \mathrm{mg} / \mathrm{m}^{3}$ & $\begin{array}{l}\text { Decreased scent, nasal congestion, inflammation, allergies and } \\
\text { increased risk associated with chronic respiratory diseases. }\end{array}$ \\
\hline Nicotine $(0-3.6 \%)$ & $\begin{array}{c}0,0004 \mathrm{mg} / \mathrm{m}^{3} \text { (daily average) } \\
0.008 \mathrm{mg} / \mathrm{m}^{3} \text { (maximum } \\
\text { single dose) }\end{array}$ & $\begin{array}{l}\text { Psychoactive substance. There may be hyperglycemia, arterial } \\
\text { hypertension, tachycardia, arrhythmia, angina pectoris, coronary heart } \\
\text { disease, heart failure and myocardial infarction. In combination with } \\
\text { resins, nicotine promotes the development of cancer, including lung } \\
\text { cancer, tongue, and larynx. Promotes the development of gingivitis and } \\
\text { stomatitis. }\end{array}$ \\
\hline $\begin{array}{c}\text { Dyes (giving color liquid): } \\
\text { 1. Auramine (yellow) } \\
\text { 2.Giroonange-benzolazobetanaphthol } \\
\text { (orange) } \\
\text { 3.Rhodamine (raspberry red) } \\
\text { 4. Auramine and } \\
\text { 1,4-diparatoluidinoantraquinone (green) }\end{array}$ & $\begin{array}{l}\text { 1. No data } \\
\begin{array}{l}\text { 2.0.1 mg / } \mathrm{m}^{3} \\
\text { 3. } 0.4 \mathrm{mg} / \mathrm{m}^{3} \\
\text { 4.No data }\end{array}\end{array}$ & $\begin{array}{l}\text { 1. This substance can cause cancer. } \\
\text { 2. Slight irritation of the skin, eyes and respiratory tract } \\
\text { 3. Sweating and cracking of the skin on the palms, thinning and brittle } \\
\text { nails, chronic bronchitis, gastritis, liver and biliary tract diseases. } \\
\text { Possible changes in the nervous system and blood } \\
\text { 4. No data }\end{array}$ \\
\hline $\begin{array}{l}\text { Flavors (creating aroma and taste; } 5-30 \% \text { ): } \\
\text { 1.Pulegone } \\
\text { 2. Diacetyl } \\
\text { 3.Acetylpropionyl } \\
\text { 4. Acetoin }\end{array}$ & $\begin{array}{l}\text { 1.No data } \\
2.2 \mathrm{mg} / \mathrm{L} \\
3.2 \mathrm{mg} / \mathrm{m}^{3} \\
4.1 \mathrm{mg} / \mathrm{m}^{3}\end{array}$ & $\begin{array}{l}\text { 1. Carcinogenic effect } \\
\text { 2. Obliterating bronchiolitis } \\
\text { 3. Obliterating bronchiolitis } \\
\text { 4. Obliterating bronchiolitis }\end{array}$ \\
\hline
\end{tabular}

\section{Conclusion}

a) Substances comprising the liquid for electronic cigarettes are unsafe for human consumption, have low value of MAC (maximum allowable concentration) and negatively affect all the body functional systems.

b) Women's addiction to smoking is stronger. c) The addiction to smoking electronic cigarettes is so strong that almost 80 per cent of the respondents have smoked for a long period (from 1 year to 7 years).

d) Pleasant flavor, fashion for vaping and misconception of their harmlessness are the most common reasons for the respondents to buy the device for the first time. 
e) More than half of the respondents cannot do not stop smoking other tobacco products alongside the electronic cigarette.

f) Almost one-third of the students surveyed admit preferring common cigarettes to vapes, though smoking vapes more often.

\section{References}

1. Christopher J Brown, James M Cheng (2014) Electronic cigarettes: product characterization and design considerations. Tob Control BMJ 23(Suppl 2): 4-10.

2. Grana R, Benowitz N, Glantz SA (2014) E-cigarettes: a scientific review. Circulation 129(19): e490-e492.

ISSN: 2574-1241

DOI: $10.26717 /$ BJSTR.2021.33.005462

Laushkin MA. Biomed J Sci \& Tech Res

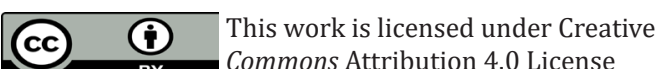

Submission Link: https://biomedres.us/submit-manuscript.php
3. McAuley TR, Hopke PK, Zhao J, Babaian S (2012) Comparison of the effects of e-cigarette vapor and cigarette smoke on indoor air quality. Inhalation Toxicology 24(12): 850-857.

4. Tianrong Cheng (2014) Chemical evaluation of electronic cigarettes. Tobacco Control BMJ Publishing Group Ltd 23: 11-17.

5. (2015) US Department of Health and Human Services. Biological and physiological effects of e -cigarette aerosol mixtures (R01): funding opportunity announcement.

6. (2014) Electronic Nicotine Delivery Systems. WHO report. Conference of the Parties to the WHO Framework Convention on Tobacco Control.

7. (2019) Who report on the global tobacco epidemic.

BIOMEDICAL
RESEARCHES $\quad \begin{aligned} & \text { Assets of Publishing with us } \\ & \text { - Global archiving of articles }\end{aligned}$

